\title{
Monocyte to HDL Ratio in The Prediction of Carotid Artery Intima-Media Thickness
}

\section{Karotis Arter Intima-Media Kalınlığının Tahmininde Monosit-HDL Oranı}

\author{
(1)Sabri Abuş, DErdal Aktürk \\ Adıyaman Kahta State Hospital, Clinic of Cardiology, Adıyaman Turkey \\ Malatya Turgut Özal University, Faculty of Medicine, Department of Cardiology, Malatya, Turkey \\ Copyright@Author(s) - Available online at www.dergipark.org.tr/tr/pub/medr \\ Content of this journal is licensed under a Creative Commons Attribution-NonCommercial 4.0 International License.
}

\begin{abstract}
Aim: In this study, we aimed to determine whether an increased monocyte count to high-density lipoprotein (MHR) would predict increased carotid intima-media thickness (IMT).

Material and Method: All consecutive subjects presenting to the cardiology outpatient clinic of our institute were enrolled in this cross-sectional study. Subjects with cardiovascular and inflammatory diseases were excluded. Subjects were divided into two groups according to carotid IMT: those with carotid IMT $>0.9 \mathrm{~mm}$ (increased) and those with carotid IMT $\leq 0.9 \mathrm{~mm}$ (normal). The difference in MHR between the two groups was the primary outcome measure of the study.

Results: The MHR of the subjects with increased IMT was significantly higher than that of subjects with normal IMT (16.7 \pm 5.7 vs. $12.8 \pm 5.5, \mathrm{p}<0.001)$. Logistic regression analysis demonstrated that age (OR: 1.202, 95\% Cl: 1.126-1.284, $\mathrm{p}<0.001)$ and MHR (OR: $1.190,95 \% \mathrm{Cl}: 1.097-1.291, \mathrm{p}<0.001)$ were significant predictors for a carotid IMT of $>0.9 \mathrm{~mm}$. ROC curve analysis revealed an MHR value of 13.4 as a cut-off in the identification of subjects that had increased IMT, with a sensitivity of $72 \%$ and specificity of $60.7 \%$. Conclusion: The inflammation marker MHR can be used as a simple and cost-effective marker to predict increased carotid IMT which is accepted as the indicator of subclinical atherosclerosis.
\end{abstract}

Keywords: Coronary artery disease, monocytes, high density lipoprotein, HDL, carotid intima-media thickness

Öz

Amaç: Bu çalışmada, artmış monosit sayısının yüksek yoğunluklu lipoprotein düzeylerine oranı (MHO)'nun artmış karotis intima-media kalınlığı (iMK)'yi yordayıp yordamayacağını belirlemeyi amaçladık.

Materyal ve Metot:Kurumumuzun kardiyoloji polikliniğine ayaktan başvuran ardışı tüm olgular bu kesitsel çalışmaya alındı. Kardiyovasküler ve enflamatuar hastalıkları olan olgular hariç tutuldu. Olgular karotis iMK'ye göre iki gruba ayrıldı: karotis iMK $>0,9 \mathrm{~mm}$ (artmış) ve karotis iMK $\leq 0.9 \mathrm{~mm}$ (normal) olanlar. MHO'daki iki grup arasındaki fark, çalışmanın birincil sonuç ölçütüdür.

Bulgular. Artmış iMK'ye sahip olguların MHO'su, normal IMK'ye sahip olgulardan anlamlı olarak daha yüksekti $(16,7 \pm 5,7$ 'ye karşı $12,8 \pm 5,5 ; p<0,001)$. Lojistik regresyon analizi, yaşın (OR: 1,202, 95\% Cl: 1,126-1,284; $p<0,001)$ ve MHR (OR: 1,190, 95\% Cl: 1,0971,$291 ; p<0,001$ )'nin >0,9 mm'lik bir karotis IMK'si için önemli prediktörler olduğunu gösterdi. ROC eğrisi analizi, \%72 duyarlılık ve \%60,7 özgüllük ile 13,4'lük bir MHO kesme değerinin artmış IMK'nin saptanmasında kullanılabileceğini gösterdi.

Sonuç: Enflamasyon belirteci MHO, subklinik aterosklerozun göstergesi olarak kabul edilen artmış karotis iMK'sini tahmin etmek için basit ve maliyet-etkin bir belirteç olarak kullanılabilir.

Anahtar Kelimeler : Koroner arter hastalığı, monositler, yüksek yoğunluklu lipoprotein, HDL, karotis intima-media kalınlığı 


\section{INTRODUCTION}

Coronary artery disease (CAD) is the leading cause of morbidity and mortality worldwide. Despite the gradual decline in the mortality of CAD over the last decades, particularly in the western world, CAD is still responsible for one-third of all deaths among individuals older than 35 years (1-3). The overall disease burden and related morbidity and mortality of CAD have led to a search for solutions that could aid early diagnosis and management. It is now well-known that early diagnosis and interventions, even in subjects without symptoms, improves prognosis. Carotid artery intimamedia thickness (IMT) is utilized as a non-invasive measurement of early atherosclerotic changes in the carotid artery wall. It is a surrogate marker for subclinical cardiovascular disease and cardiovascular events $(4,5)$. The ACCF/AHA guidelines recommend using carotid IMT for the assessment of individuals presenting with an intermediate risk of CAD (6). Despite its wide availability, measurement of carotid IMT is time-consuming and requires familiarity with the technique.

Since inflammation is one of the basic hallmarks of atherosclerosis, and the monocytes are a major component of the inflammatory processes during atherosclerosis, monocyte to high-density lipoprotein cholesterol (HDL) ratio (MHR) -which is associated with inflammation- has recently been investigated in subjects with atherosclerotic cardiovascular disease $(7,8)$. However, the role of MHR in the prediction of subclinical atherosclerosis has not been studied yet. Given the strong association between the inflammatory state and MHR, we hypothesized that MHR would be higher in subjects with subclinical atherosclerosis.

The present study aimed to compare MHR values in subjects with and without increased carotid IMT and determine whether increased MHR would predict increased carotid IMT.

\section{MATERIAL AND METHOD}

\section{Study Design}

All consecutive subjects aged between 30 and 60 years admitted to our institute's cardiology outpatient clinic, and between June 2017 and August 2017, were enrolled in this cross-sectional study. Subjects with diabetes mellitus, hypertension, or any structural or functional cardiovascular disease on cardiac examination and screening tests (including electrocardiography and echocardiography) were excluded from the study. To diminish any confounders that might influence monocyte levels, subjects with any hematological, immunological, or inflammatory disease that could result in monocytosis were excluded from the study, as well as patients with malignancies and those receiving corticosteroid therapy. The protocol was approved based on the ethical standards of the Declaration of Helsinki. The permissions and consents required for the study were obtained from the Adıyaman University Biomedical Research Ethics
Committee (Approval number $=2017 / 3-7$ ). Informed consent was obtained from the subjects.

Fasting venous blood samples were obtained, and the following parameters were measured: complete blood count, fasting glucose, urea, creatinine, $C$-reactive protein, and lipid profile (Olympus AU-640 analyzer, Mishima Olympus Co. Ltd, Shizuoka, Japan). At the Adiyaman University Training and Research Hospital biochemistry laboratory, hematological parameters were studied on the "CELL-DYN 3700 SL analyzer (Abbott Diagnostics, Chicago, U.S.A.)" device. Existing cigarette smoking was defined as $>10$ cigarettes per day. Body mass index (BMI) was calculated using the standard formula of weight $(\mathrm{kg}) /$ height squared (m2). A detailed medical history of each subject was also recorded. All participants underwent transthoracic echocardiography and carotidintima-media thickness measurement with a commercially available cardiac ultrasound system (Vivid E9, GE Medical Systems, Horten, Norway). The left lateral decubitus pose was used for all patients. All patients were examined in detail using thestandard two-dimensional echocardiographicmethod. The same investigator performed all measurements.

\section{Primary Outcome}

Subjects were divided into two groups according to carotid IMT values: Those with a carotid IMT greater than $0.9 \mathrm{~mm}$ (increased IMT group) and those with a carotid IMT equal to or lower than $0.9 \mathrm{~mm}$ (normal IMT group) $(9,10)$. The difference in MHR values between the two groups and the relationships between MHR and carotid IMT values were the primary and secondary outcome measures of the study.

\section{Statistical Analysis}

All analyses were performed on SPSS version 21 (SPSS Inc., Chicago, IL, USA). The sample was divided into two based on the carotid IMT $0.9 \mathrm{~mm}$. Student t-test was used to analyze the differences in numerical data between groups, and a chi-square test was used to analyze the differences of categorical data. Correlation analysis was performed to evaluate the relationship between carotid IMT and MHR, sociodemographic characteristics, and blood parameters. Logistic regression analysis was applied to measure the effect of age, smoking, BMI, and blood parameters on carotid IMT. ROC curve analysis has used the sensitivity and specificity of MHR for predicting carotid artery IMT. The values less than 0.05 were accepted to show statistically significant relationships.

\section{RESULT}

A total of 200 subjects (mean age $41.7 \pm 8.6$ years, $49.5 \%$ male) were enrolled in this cross-sectional study. Carotid IMT was $>0.9 \mathrm{~mm}$ in 50 of the participants (mean carotid IMT $0.93 \pm 0.1 \mathrm{~mm}$ ) and was $\leq 0.9 \mathrm{~mm}$ in the remaining 150 participants (mean carotid IMT $0.56 \pm 0.1 \mathrm{~mm}$ ).

Demographic features and laboratory measurements of the study groups are presented in Table 1. Age, BMI, fasting glucose level, active smoking, total and LDL 
cholesterol, monocyte count, and platelet count were significantly higher in subjects with increased carotid IMT than normal carotid IMT. The MHR of the subjects with increased carotid IMT was also substantially higher than that of subjects with normal carotid IMT values $(16.7 \pm$ 5.7 vs. $12.8 \pm 5.5, p<0.001)$.

As shown in Table 2, correlation analysis revealed that carotid IMT was significantly correlated with MHR $(r=0.325, p<0.001)$, age $(r=0.893, p<0.001)$, monocyte count $(r=0.261, p<0.001)$, fasting glucose $(r=0.261$, $p<0.001)$, blood urea nitrogen $(r=0.184, p<0.001)$, total cholesterol $(r=0.356, p<0.001)$, LDL cholesterol $(r=0.313$, $p<0.001)$, triglyceride level $(r=0.293, p<0.001)$, leukocyte count $(r=0.185, p=0.009)$, neutrophil count $(r=0.148$, $p=0.037)$, lymphocyte count $(r=0.153, p=0.037)$, whereas it was negatively correlated with HDL cholesterol level $(r=-0.210, p=0.003)$.

Logistic regression analysis demonstrated that age (OR: 1.202, 95\% Cl: 1.126-1.284, p<0.001) and MHR (OR: 1.190, 95\% Cl: 1.097-1.291, $\mathrm{p}<0.001$ ) were significant predictors for a carotid IMT of $>0.9 \mathrm{~mm}$ (Table 3 ). ROC curve analysis revealed an MHR cut-off value of 13.4 to identify subjects with increased carotid IMT with a sensitivity of $72 \%$ and specificity of $60.7 \%$ (Figure 1 ).

\begin{tabular}{|c|c|c|c|}
\hline & $\begin{array}{c}\text { Carotid IMT } \leq 0.9 \mathrm{~mm} \\
\qquad(\mathrm{n}=150)\end{array}$ & $\begin{array}{l}\text { Carotid IMT > } 0.9 \mathrm{~mm} \\
\qquad(\mathrm{n}=50)\end{array}$ & p value \\
\hline Age (year) & $38.5 \pm 6.6$ & $51.4 \pm 6.6$ & $<0.001 * *$ \\
\hline Gender, Female (n, \%) & $76(50.7 \%)$ & $25(50 \%)$ & 0.935 \\
\hline Smoking (n, \%) & $118(78.7 \%)$ & $49(98 \%)$ & $<0.001 * *$ \\
\hline BMI (kg/m2) & $28 \pm 4.6$ & $27.8 \pm 3.4$ & $0.010 *$ \\
\hline Carotid IMT (mm) & $0.56 \pm 0.1$ & $0.93 \pm 0.1$ & $<0.001 * *$ \\
\hline Glucose $(\mathrm{mg} / \mathrm{dL})$ & $72.8 \pm 26.4$ & $125.5 \pm 35.2$ & $0.003 *$ \\
\hline BUN (mg/dL) & $28 \pm 8.7$ & $29.4 \pm 7.3$ & 0.161 \\
\hline Creatinine (mg/dL) & $0.73 \pm 0.16$ & $0.75 \pm 0.19$ & 0.156 \\
\hline Total Cholesterol (mg/dL) & $180.8 \pm 40.7$ & $204.8 \pm 42.2$ & $0.002 *$ \\
\hline HDL Cholesterol (mg/dL) & $43.3 \pm 9.4$ & $40.7 \pm 7.7$ & 0.052 \\
\hline LDL Cholesterol (mg/dL) & $105 \pm 30.6$ & $122.2 \pm 32.3$ & 0.001 * \\
\hline Triglyceride (mg/dL) & $157.8 \pm 88.3$ & $192.6 \pm 115.4$ & 0.060 \\
\hline WBC (/mm3) & $8459.9 \pm 1968.5$ & $8948.3 \pm 1740.3$ & 0.069 \\
\hline Hemoglobin (g/dL) & $15.7 \pm 8.9$ & $15.8 \pm 11.7$ & 0.289 \\
\hline Neutrophil Count (/mm3) & $4891.6 \pm 1574.1$ & $5074.8 \pm 1393.6$ & 0.337 \\
\hline Lymphocyte Count (/mm3) & $2637.9 \pm 777$ & $2886.8 \pm 944.7$ & 0.138 \\
\hline Monocyte Count (/mm3) & $525.6 \pm 187.4$ & $657.6 \pm 185.8$ & $<0.001 * *$ \\
\hline Platelet Count (x103/mm3) & $251.2 \pm 124.8$ & $277.3 \pm 92.1$ & 0.133 \\
\hline MHR & $12.8 \pm 5.5$ & $16.7 \pm 5.7$ & $<0.001 * *$ \\
\hline CRP (mg/L) & $0.43 \pm 0.43$ & $0.75 \pm 0.19$ & 0.014 \\
\hline
\end{tabular}




\begin{tabular}{|c|c|c|}
\hline & & \\
\hline & $\mathbf{r}$ & $\mathbf{p}$ \\
\hline MHR & 0.325 & $<0.001$ ** \\
\hline HDL Cholesterol & -0.210 & $0.003 *$ \\
\hline Monocyte Count & 0.261 & $<0.001 * *$ \\
\hline Age & 0.893 & $<0.001$ ** \\
\hline Gender & 0.096 & 0.175 \\
\hline BMI & 0.129 & 0.070 \\
\hline Smoking & -0.127 & 0.073 \\
\hline Fasting Glucose & 0.261 & $<0.001$ ** \\
\hline BUN & 0.184 & 0.009 * \\
\hline Creatinine & 0.070 & 0.325 \\
\hline CRP & 0.035 & 0.620 \\
\hline Total Cholesterol & 0.356 & $<0.001$ ** \\
\hline LDL Cholesterol & 0.313 & $<0.001$ ** \\
\hline Triglyceride & 0.293 & $<0.001$ ** \\
\hline Leukocyte Count & 0.185 & $0.009 *$ \\
\hline Hemoglobin & -0.012 & 0.871 \\
\hline Neutrophil Count & 0.148 & $0.037 *$ \\
\hline Lymphocyte Count & 0.153 & $0.030 *$ \\
\hline Platelet Count & 0.037 & 0.601 \\
\hline
\end{tabular}

Table 3. Logistic Regression Analysis Demonstrating the Predictors of Increased Carotid IMT

\section{Odds ratio}

Age

BMI

Smoking

Glucose

BUN

Total Cholesterol

LDL Cholesterol

Triglyceride

MHR
1.202

0.993

0.083

1.001

0.987

1.010

0.987

0.966

1.190
95\% Confidence Interval

$1.126-1.284$

$0.875-1.128$

$0.051-1.202$

0.995-1.008

0.937-1.039

0.986-1.034

0.963-1.012

0.990-1.002

1.097-1.291 p value

$<0.001$ **

0.920

0.083

0.750

0.611

0.415

0.316

0.235

$<0.001$ ** 


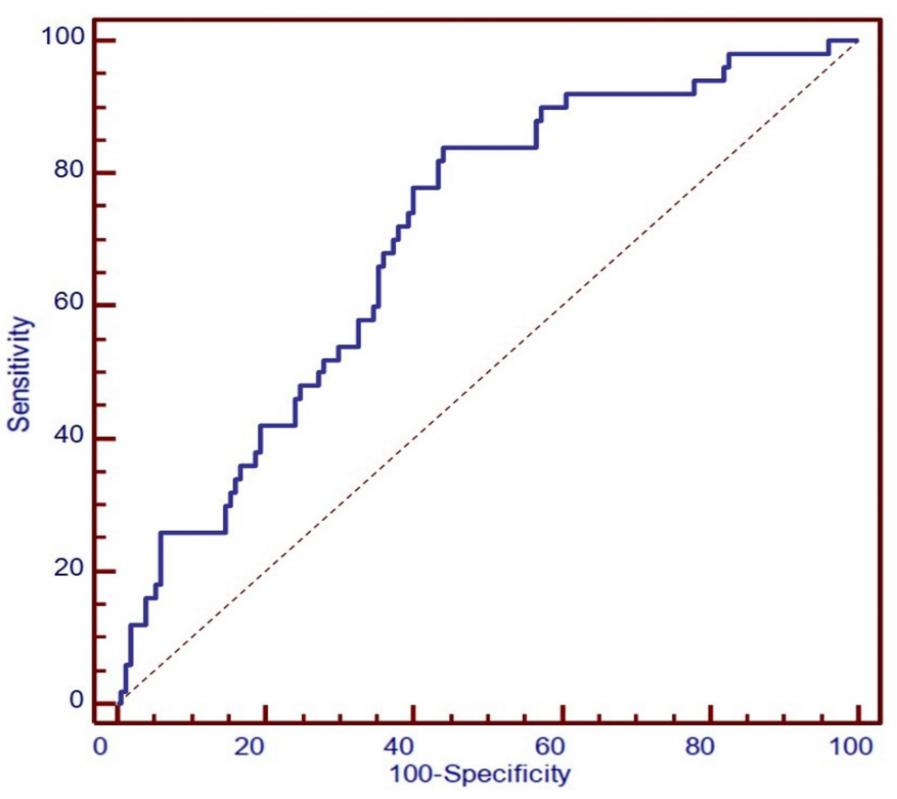

Figure 1. ROC Curve Demonstrating the Sensitivity and Specificity of Monocyte to HDL Ratio for Predicting Carotid Artery Intima Media Thickness

\section{DISCUSSION}

Results of the present study demonstrate that MHR is significantly higher in subjects with increased carotid IMT. In addition to the significant correlation between MHR and carotid IMT, MHR was an independent predictor of increased carotid IMT. Moreover, MHR can identify subjects with increased carotid IMT with relatively high sensitivity even though specificity was moderate. These results are promising, particularly when considering that they were obtained from a consecutively enrolled patient group that did not include those with known heart diseases.

Currently, CAD is accepted as a multifactorial disease, and the healing response to vascular injury is considered to allow the initiation and progression of the atherosclerotic plaque (9-11). The presence of hypercholesterolemia is the primary trigger for the initiation of atherosclerosis. In the next step, monocytes adhere to the vascular endothelium and migrate through mechanisms that involve VCAM-1 and selectins. Oxidation of the LDL promotes the secretion of the macrophage chemotactic protein 1. Monocytes change into macrophages within the arterial intima and express scavenger receptors, thus converting into foamy macrophages, which play a critical role in the occurrence and development of atherosclerosis (12). Beyond their activity inside the arterial wall, several immune stimulatory agents and cytokines presenting in blood circulation affect the circulating monocytes and, therefore, contribute to the pathogenesis of CAD and its complications (13). In this briefly explained the complex process, inflammatory activity is likely responsible for plaque instability which may promote plaque rupture, fissuring, or erosion; thus, resulting in the acute presentations of CAD such as unstable angına (14).
High-density lipoprotein, which has been acknowledged as an anti-atherosclerotic lipoprotein under normal physiological conditions, neutralizes the atherosclerotic role of the monocytes. Also, HDL provides various anti-atherosclerotic properties, independent from the monocyte-blockingfunctions(15-19). Theatherosclerotic functions of the monocytes and monocyte-blocking properties possessed by HDL have led to the suggestion that MHR could be a valuable indicator of atherosclerosis. Tanietal. havedemonstratedinan intravascularultrasound study of 114 patients with established CAD that treatment with $40 \mathrm{mg}$ pravastatin leads to a significant reduction in plaque volume and monocyte count in addition to a significant increase in HDL cholesterol level. Multivariate analyses revealed that the rise in serum HDL cholesterol and decreased monocyte count were independent predictors of plaque regression (19). Kundi et al. (20) have shown in 428 patients with stable CAD that MHR was significantly higher in patients with high Syntax scores $(\geq$ 23) and that an MHR value $>24$ was predictive for a high Syntax score with a sensitivity of $66 \%$ and a specificity of $65.1 \%$. Two studies conducted by Akboga et al. have reported that MHR could independently predict CAD as indicated by the high $(\geq 23)$ Syntax score and saphenous vein graft stenosis of $>50 \%(21,22)$. Several studies also demonstrate the association between an increased MHR and stent thrombosis, stent restenosis, and no-reflow phenomenon after $\mathrm{PCl}$ of the infarct-related artery, inhospital MACE, and even with in-hospital mortality and long-term mortality (23-26).

This study is the first to report the predictive role of MHR on carotid IMT. Our findings demonstrate that MHR value is significantly correlated with carotid CIMT and that an MHR value of $>13.4$ was predictive for increased carotid IMT $(\geq 0.9 \mathrm{~mm})$. Given its correlation with carotid IMT and its role in identifying increased carotid IMT, we suggest that the calculation of MHR can be used as a simple, cost-effective, and highly predictive marker of subclinical atherosclerosis. Combining MHR with carotid IMT in subjects with established CAD will probably increase the carotid IMT in predicting the early stages of atherosclerosis. Further studies are required to address the usefulness of the combination of MHR and carotid IMT in detecting subclinical atherosclerosis.

This study also has some limitations to be mentioned. Although we suggest that MHR values are predictive for the presence of subclinical atherosclerosis, this suggestion arises from the assumption that carotid IMT is a robust predictor for the early stages of atherosclerosis. However, the golden standard for detecting atherosclerosis is coronary angiography; however, the study population included in this study did not have CAD established by coronary angiography. Although this is a limitation concerning its usefulness in evaluating the degree of CAD and relationships with other parameters associated with CAD, it is also an advantage in determining its efficacy in previously healthy populations. Additionally, increased carotid IMT is currently accepted as an indicator of 
endothelial dysfunction and early atherosclerosis; therefore, the correlation between MHR values and increased carotid IMT is very likely an indication of the presence of subclinical atherosclerosis.

\section{CONCLUSION}

The Monocyte-to-HDL ratio is significantly correlated with carotid IMT values. MHR also appears as an independent predictor of increased carotid IMT. We suggest that MHR can be used as a cost-effective and straightforward marker of inflammation for predicting the presence of increased carotid IMT, which is accepted as a reliable indicator of subclinical atherosclerosis.

The authors declare that this study has received no financial support.

Conflict of Interest: The authors declare that they have no competing interest.

Ethical approval: The protocol was approved based on the ethical standards of the Declaration of Helsinki. The permissions and consents required for the study were obtained from the Adıyaman University Biomedical Research Ethics Committee (Approval number $=2017 / 3$ 7). Informed consent was obtained from the subjects.

\section{REFERENCES}

1. Nichols M, Townsend N, Scarborough P, et al. Cardiovascular disease in Europe 2014: epidemiological update. Eur Heart J. 2014 ; 35: 2929.

2. Cervellin G, Lippi G. Of Mls and men--a historical perspective on the diagnostics of acute myocardial infarction. Semin Thromb Hemost. 2014;40:535-43.

3. Sanchis-Gomar F, Perez-Quilis C, Leischik R, et al. Epidemiology of coronary heart disease and acute coronary syndrome. Ann Transl Med. 2016;4:256.

4. Polak JF, O'Leary DH. Carotid Intima-Media Thickness as Surrogate for and Predictor of CVD. Glob Heart. 2016;11:295312.

5. Heuten H, Goovaerts I, Ennekens G, et al. Carotid artery intima-media thickness is associated with coronary artery disease. Acta Cardiol. 2008;63:309-13.

6. Greenland P, Alpert JS, Beller GA, et al. 2010 ACCF/ AHA guideline for assessment of cardiovascular risk in asymptomatic adults: a report of the American College of Cardiology Foundation/American Heart Association Task Force on Practice Guidelines. J Am Coll Cardiol. 2010;56:e50-103.

7. Acikgoz N, Kurtoğlu E, Yagmur J, et al. Elevated monocyte to high-density lipoprotein cholesterol ratio and endothelial dysfunction in behçet disease. Angiology. 2018;69:65-70.

8. Bolayir A, Gokce SF, Cigdem B,et al. Monocyte/high-density lipoprotein ratio predicts the mortality in ischemic stroke patients. Neurol Neurochir Pol. 2018;52:150-5.

9. Authors/Task Force Members, Rydén L, Grant PJ, et al. ESC Guidelines on diabetes, pre-diabetes, and cardiovascular diseases developed in collaboration with the EASD: the Task Force on diabetes, pre-diabetes, and cardiovascular diseases of the European Society of Cardiology (ESC) and developed in collaboration with the European Association for the Study of Diabetes (EASD). Eur Heart J. 2013;34:303587.

10. Piepoli MF, Hoes AW, Agewall S, et al. 2016 European Guidelines on cardiovascular disease prevention in clinical practice: The Sixth Joint Task Force of the European Society of Cardiology and Other Societies on Cardiovascular Disease Prevention in Clinical Practice (constituted by representatives of 10 societies and by invited experts) Developed with the special contribution of the European Association for Cardiovascular Prevention \& Rehabilitation (EACPR). Eur Heart J. 2016;37:2315-81.

11. Wexler L, Brundage B, Crouse J, et al. Coronary artery calcification: pathophysiology, epidemiology, imaging methods, and clinical implications. A statement for health professionals from the American Heart Association. Writing Group. Circulation. 1996;94:1175-92.

12. Ali M, Girgis $S$, Hassan A, et al. Inflammation and coronary artery disease: from pathophysiology to Canakinumab AntiInflammatory Thrombosis Outcomes Study (CANTOS). Coron Artery Dis. 2018;29:429-37.

13. Gratchev A, Sobenin I, Orekhov A, et al. Monocytes as a diagnostic marker of cardiovascular diseases. Immunobiology. 2012; 217:476-82.

14. Harrington RA. Targeting inflammation in coronary artery disease. N Engl J Med. 2017; 377:1197-8.

15. Ossoli A, Remaley AT, Vaisman B,et al. Plasma-derived and synthetic high-density lipoprotein inhibit tissue factor in endothelial cells and monocytes. Biochem J. 2016;473:2119.

16. Heitzer T, Schlinzig T, Krohn K, et al. Endothelial dysfunction, oxidative stress, and risk of cardiovascular events in patients with coronary artery disease. Circulation. 2001;104:2673-8.

17. Usta A, Avci E, Bulbul CB, et al. The monocyte counts to HDL cholesterol ratio in obese and lean patients with polycystic ovary syndrome. Reprod Biol Endocrinol. 2018;16:34.

18. Gomaraschi M, Basilico N, Sisto F, et al. High-density lipoproteins attenuate interleukin-6 production in endothelial cells exposed to pro-inflammatory stimuli. Biochim Biophys Acta. 2005;1736:136-43.

19. Tani S, Matsumoto M, Anazawa T, et al. Development of a model for prediction of coronary atherosclerotic regression: evaluation of high-density lipoprotein cholesterol level and peripheral blood monocyte count. Heart Vessels. 2012;27:143-50.

20. Kundi H, Kiziltunc E, Cetin M, et al. Association of monocyte/ HDL-C ratio with SYNTAX scores in patients with stable coronary artery disease. Herz. 2016;41:523-9.

21. Akboga MK, Balci KG, Maden O, et al. Usefulness of monocyte to HDL-cholesterol ratio to predict high SYNTAX score in patients with stable coronary artery disease. Biomark Med. 2016;10:375-83.

22. Akboga MK, Yayla C, Balci KG, et al. Relationship between serum albumin level and monocyte-to-high-density lipoprotein cholesterol ratio with saphenous vein graft disease in coronary bypass. Thorac Cardiovasc Surg. 2017;65:315-21. 
23. Açıkgöz SK, Açıkgöz E, Şensoy B, et al. Monocyte to highdensity lipoprotein cholesterol ratio is predictive of inhospital and five-year mortality in ST-segment elevation myocardial infarction. Cardiol J. 2016;23:505-12.

24. Tok D, Turak O, Yayla Ç, et al. Monocyte to HDL ratio in prediction of BMS restenosis in subjects with stable and unstable angina pectoris. Biomark Med. 2016;10:853-60.
25. Balta S, Celik T, Ozturk $\mathrm{C}$, et al. The relation between monocyte to HDL ratio and no-reflow phenomenon in the patients with acute ST-segment elevation myocardial infarction. Am J Emerg Med. 2016;34:1542-7.

26. Cetin MS, Ozcan Cetin EH, Kalender E, et al. Monocyte to HDL cholesterol ratio predicts coronary artery disease severity and future major cardiovascular adverse events in acute coronary syndrome. Heart Lung Circ. 2016;25:1077-86. 